\title{
Evaluating Brazilian Conservation Projects: the Weak Link between Practice and Theory
}

\author{
Flávia Pereira Lima1, José Norberto Muniz² \& Paulo de Marco Júnior,**
}

\author{
${ }^{1}$ Centro de Ensino e Pesquisa Aplicada à Educação, Universidade Federal de Goiás - UFG, Goiânia, GO, Brasil \\ ${ }^{2}$ Departamento de Economia Rural, Universidade Federal de Viçosa - UFV, Viçosa, MG, Brasil \\ ${ }^{3}$ Laboratório de Ecologia Teórica e Síntese, Departamento de Ecologia, Instituto de Ciências Biológicas, \\ Universidade Federal de Goiás - UFG, Goiânia, GO, Brasil
}

\begin{abstract}
Conservation Biology is a scientific discipline devoted to producing practical actions strongly based on scientific fundamentals. We have recognized a gap between the available knowledge and intervention practices, which could be diminished by the application of monitoring methods and a research evaluation framework. Using this approach, we aimed to understand if conservationists in Brazil link theoretical themes to practical issues in their research projects through the analysis of 115 project objectives funded by FNMA (National Environmental Fund) in Flora and Fauna Sustainable Management category. The most cited theoretical themes are population biology, biodiversity assessment and ecosystem services, while instruments for conservation species management and education were the most cited practical themes. There was only a weak association between theoretical and practical themes within projects. Our analyses suggested the importance of investment in educating conservation professionals about the social and political context of conservation and encouraging the elaboration of projects with more properly designed interactions between biological research and intervention actions.
\end{abstract}

Key words: Evaluation Research, Conservationist Projects, Conservation Themes, Intervention, Fauna and Flora Management.

\section{Introduction}

At the end of the 1970s and into the early 1980s, Conservation Biology emerged as a scientific discipline to response to the increasing rates of species extinction and other threats to biodiversity (Wilson 1985). Conservation Biology uses a multidisciplinary approach that includes biological and social perspectives in its framework of analysis (Soule 1985). Considered a crisis-oriented discipline due to the urgent necessity for designing interventionist actions even under the constraints of incomplete scientific knowledge, Conservation Biology addresses the main problems related to the conservation of species, their communities and ecosystems (Soule 1985).

Above all, Conservation Biology has been assured scientific status, developing theories to understand conservation questions that usually refer to certain patterns in nature, relationships among entities and processes, and causes of these patterns and their differences (Pickett et al. 1994).

\footnotetext{
* Send correspondence to: Paulo de Marco Júnior Departamento de Ecologia, ICB, Universidade Federal de Goiás - UFG, CP 131, CEP 74001-970, Goiânia, GO, Brasil E-mail:pdemarco@pq.cnpq.br
}

Theory, under this perspective, could be considered a system of conceptual constructs, implying that is composed of several components, such as domain, assumptions, concepts and definitions (Pickett et al. 1994). Natural scientists typically use theory as a generalization tool to produce a set of testable hypotheses to explain particular processes (Ford 2000).

Nevertheless, pragmatic approach to Conservation Biology appears to have reduced the impact of theory in orienting the conservationists' planning, leading to a dichotomy between academic conservation research and conservation practice (With 1997). The application of monitoring methods and evaluation of conservationist activities may be important to guide the decision process for biodiversity conservation and control uncertainties in the crisis area (Stem et al. 2005). Some fundamentals of this scientific research procedure must be presented for increasing the rationality in policy making, by generating information that can sustain the decision-making process (Berk \& Rossi 1999). An evaluation research approach could i) give feedback about the quality of ongoing programs, ii) impart information about the target 
of conservation actions, iii) provide sustainable information and data to increase knowledge about what actions produce adequate results, and iv) allow the identification of factors or variables that can be implemented for program success (Scheirer 1994).

Assuming that the use of an evaluation research framework would improve the knowledge-practice system for Conservation Biology, we analyzed 115 funded projects in Flora and Fauna Sustainable Management category from FNMA (National Environmental Fund). This fund has an institutional mission to implement the National Environmental Policy, providing financial support to projects focusing on environmental problems. Therefore, we raise a simple question the basis of this work: Do conservationists use theoretical themes that have their origin in scientific knowledge with a clear link to practical actions or practical conservationist proposals?

From the results obtained in the analysis of FNMA projects, we also tried to suggest some considerations in order to improve the proposals of conservationist interventions. Although our focus was on the Brazilian conservationists' approach to those issues, the questions that we address here are broad in scope, go deep into the foundations of Conservation Biology as a discipline and may have clear parallels in other countries, at least in South America.

\section{Methods}

The empirical reference for the investigation was the “Catálogo de Experiências/1990-2001" (Fundo Nacional do Meio Ambiente 2002), which presented all the research projects recommended and approved during that period (a total of 710). There were 118 projects (17\%) funded under the category of "Flora and Fauna Sustainable Management." The information provided included title, objectives, thematic issue, institution executor, institution executor's state, funding resources, funding from other sources and execution period. We considered this information for the research projects that presented the closest relation to Conservation Biology research. From this first approach, we disregarded three projects which were the resubmission of the same proposal.

The initial reference for the analysis was the project's objectives. We identified the main terms and meanings and compared them with the theoretical themes employed in Conservation Biology (Table 1) based on Caughley (1994), Sutherland (2001), Trombulak et al. (2004) and Costanza et al. (1997). Themes included broad research areas (e.g., population biology) or more specific ecological concepts (e.g., population viability) representing a general description of the main conservation issues that deserve special attention from conservation professionals. We followed the same procedure to identify practical actions and proposed practical actions classified using the same general theoretical background.
We assumed that if conservation biologists propose projects grounded in ecological theory, then specific theoretical themes will be associated with practical actions. For instance, we expected that species management actions (a practical theme) should be based on and appear together with population biology (a theoretical theme) because population biology theory is the basis for species management actions. Thus, we undertook a Canonical Correspondence Analysis according to methods presented in Everitt and Dunn (1991) to undercover the relationship between theoretical and practical themes. We follow an exploratory approach and used the statistical tests only as an indicator to choose axes and the original variable contributions to those derived axes.

\section{Results}

We found both theoretical and practical themes in only $39.1 \%$ of the projects. The most common theoretical theme was population biology (32.2\%), followed by biodiversity assessment (27.8\%) and ecosystem services (10.4\%; Table 2). The most frequent practical themes were instruments for conservation $(30.4 \%)$ followed by species management (26.9\%) and education (21.7\%, Table 2).

The low frequency of the theoretical themes reveals that the research projects' authors do not introduce the main theoretical framework of Conservation Biology in their proposals. This finding indicates that the researchers and their suggestions for primary actions for intervention were conceptualized on a strong empirical and utilitarian basis, probably to obtain quick solutions for pragmatic problems.

If Conservation Biology projects present a direct correlation between research and practical actions, we would expect that the projects presented theoretical linked to practical themes. The associations between theoretical and practical conservationist themes were weak (only the first canonical axis was statistically significant; canonical $\mathrm{R}=0.614$; $\chi^{2}=98.752 ; \mathrm{df}=64 ; \mathrm{p}<0.003$; Figure 1 ). We observed that projects that have habitat conservation as a theoretical theme usually have habitat management as a practical action (Figure 1). Surprisingly, those projects tend to not mention population biology as theoretical theme (right side of first axis, Figure 1). The general distribution of the themes in Figure 1 also suggests an association of most of the practical themes (infrastructure and sustainable use at the second axis; instruments of conservation, education and species management are clustered together). A similar association is observed between theoretical themes. A general conclusion is that some projects focus only on practical actions without presenting any theoretical associations and vice-versa.

\section{Discussion}

In Brazil, the FNMA funds many projects that facilitate environmental actions and research, which are usually interventionist in character, and it prioritizes projects with a practical approach. We observed a fragile association between theoretical and practical conservationist themes, which may 
Table 1. Theoretical and practical themes used for evaluation of Conservation Biology project objectives from Flora and Fauna Sustainable Management category.

\begin{tabular}{|c|c|c|c|}
\hline & Themes & Explanation & Project types \\
\hline \multirow{8}{*}{ 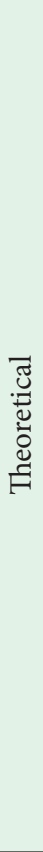 } & Biodiversity assessment & $\begin{array}{l}\text { Assessment of species abundance and } \\
\text { diversity. }\end{array}$ & $\begin{array}{l}\text { Species list; ethnobiology assessment; } \\
\text { diversity measures (richness and } \\
\text { abundance distribution). }\end{array}$ \\
\hline & Ecosystems services & $\begin{array}{l}\text { Natural functions that can, secondarily, } \\
\text { be used for human benefit. }\end{array}$ & $\begin{array}{l}\text { Any study that proposed to understand, } \\
\text { quantify or use ecosystems services. }\end{array}$ \\
\hline & $\begin{array}{l}\text { Geographic } \\
\text { distribution }\end{array}$ & $\begin{array}{l}\text { Species distributions as a function of } \\
\text { their biological characteristics and } \\
\text { evolutionary history. }\end{array}$ & $\begin{array}{l}\text { Species distribution; species distribution } \\
\text { model. }\end{array}$ \\
\hline & Habitat conservation & Conservation of habitat. & $\begin{array}{l}\text { Projects that seek recuperation of any } \\
\text { area. }\end{array}$ \\
\hline & Monitoring & $\begin{array}{l}\text { Regular evaluation of population } \\
\text { descriptors that permit the understanding } \\
\text { of time changes. }\end{array}$ & $\begin{array}{l}\text { Inventory; measures of environmental } \\
\text { variables; demographic studies. }\end{array}$ \\
\hline & Population biology & $\begin{array}{l}\text { Basic knowledge about species ecology } \\
\text { and its relation to environment. }\end{array}$ & $\begin{array}{l}\text { Natural history; behavior; physiology; } \\
\text { morphology; reproduction; genetics. }\end{array}$ \\
\hline & Population viability & $\begin{array}{l}\text { Determining the probability of } \\
\text { population persistence over time. }\end{array}$ & Studies of population viability. \\
\hline & Threatened biodiversity & $\begin{array}{l}\text { Concept linked to species extinction. The } \\
\text { main causes are: habitat destruction and } \\
\text { alteration, resources overexploitation and } \\
\text { alien species introduction. }\end{array}$ & $\begin{array}{l}\text { Projects to understand some of the } \\
\text { threatened species. }\end{array}$ \\
\hline \multirow{8}{*}{ 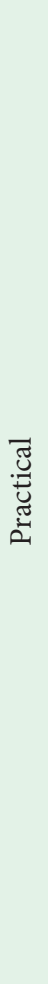 } & Education & $\begin{array}{l}\text { Educational actions to distribute } \\
\text { information and inform people about } \\
\text { environment questions. }\end{array}$ & $\begin{array}{l}\text { Divulgation of environment information, } \\
\text { educational practices, integrations } \\
\text { traditional and scientific knowledge; } \\
\text { people training. }\end{array}$ \\
\hline & $\begin{array}{l}\text { Ex situ species } \\
\text { management }\end{array}$ & $\begin{array}{l}\text { Species management in artificial } \\
\text { conditions. }\end{array}$ & $\begin{array}{l}\text { Maintenance of species for future } \\
\text { repopulation. }\end{array}$ \\
\hline & Habitat management & $\begin{array}{l}\text { Restoring natural processes, and } \\
\text { maintaining original habitats. }\end{array}$ & $\begin{array}{l}\text { Conservation and restoration of } \\
\text { conservation areas, restoration of urban } \\
\text { forest fragments. }\end{array}$ \\
\hline & Infrastructure & $\begin{array}{l}\text { Building, recuperation or maintenance } \\
\text { of structures that are destined to } \\
\text { conservation. }\end{array}$ & Building nurseries for plants; laboratories. \\
\hline & $\begin{array}{l}\text { Instruments for } \\
\text { conservation }\end{array}$ & $\begin{array}{l}\text { Elaboration of instruments that are used } \\
\text { in conservation. }\end{array}$ & $\begin{array}{l}\text { Books, maps, databases, biological } \\
\text { collections, seedlings or seeds donations, } \\
\text { market analysis. }\end{array}$ \\
\hline & Species management & $\begin{array}{l}\text { Strategies that permit species } \\
\text { conservation. Management is especially } \\
\text { important to species in decline or with } \\
\text { small population size. }\end{array}$ & $\begin{array}{l}\text { Techniques such as supplementary food; } \\
\text { removing predators; re-establishment of } \\
\text { new population; introduction of species. }\end{array}$ \\
\hline & $\begin{array}{l}\text { Sustainable use of } \\
\text { biodiversity }\end{array}$ & $\begin{array}{l}\text { Utilization of natural resources seeking } \\
\text { sustainable procedures. }\end{array}$ & $\begin{array}{l}\text { Rational use of natural resources; } \\
\text { establishment of economically sustainable } \\
\text { forest systems. }\end{array}$ \\
\hline & Technology & $\begin{array}{l}\text { Development of methods and technology } \\
\text { for conservation, recuperation and } \\
\text { sustainable use of natural resources. }\end{array}$ & $\begin{array}{l}\text { Methods of captive breeding, plant } \\
\text { management. }\end{array}$ \\
\hline
\end{tabular}

lead to a set of questions, such as: What are the consequences of this weak association? Do interventions without a scientific basis jeopardize conservation actions?

The scenario for these questions is an extremely complex system that involves natural ecosystems and human societies (Salafsky et al. 2002). Many conservationist actions imply political solutions, but their success was jeopardized by disregarding economic and social aspects of conservation (Beissinger 1990). Conservation professionals must be able to produce information and data to subsidize the political decisions made in a multi-cultural society with diverse values and perceptions about the environment 
Table 2. Occurrence frequency of theoretical and practical themes in project objectives from the theme of Flora and Fauna Sustainable Management $(\mathrm{n}=115)$.

\begin{tabular}{lr}
\hline \multicolumn{1}{c}{ Themes } & Percentage (\%) \\
\hline Theoretical themes & 27.8 \\
Biodiversity assessment & 10.4 \\
Ecosystems services & 7.0 \\
Geographic distribution & 8.7 \\
Habitat conservation & 6.1 \\
Monitoring & 32.2 \\
Population biology & 10.0 \\
Population viability & 5.2 \\
Threatened biodiversity & \\
Practical themes & 21.7 \\
Education & 1.7 \\
Ex situ species management & 17.4 \\
Habitat management & 13.0 \\
Infrastructure & 30.4 \\
Instruments for conservation & 26.9 \\
Species management & 14.8 \\
Sustainable use of biodiversity & 7.8 \\
Technology &
\end{tabular}

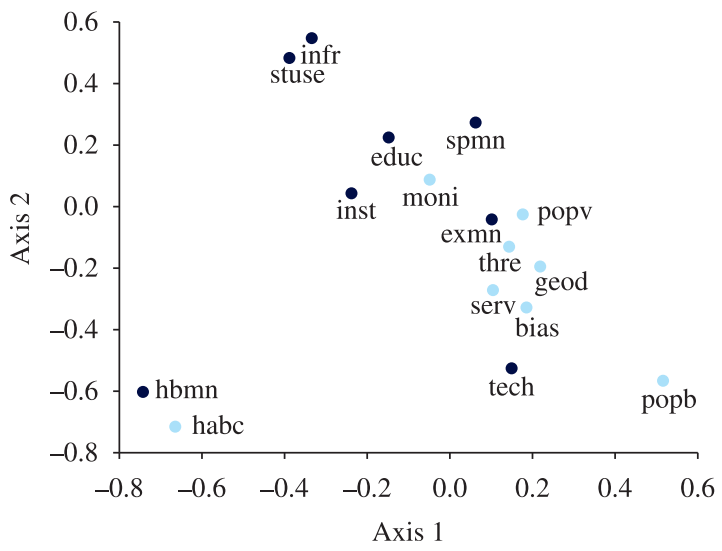

Theoretical themes $\bullet$ Practical themes

Figure 1. Results from canonical correspondence analysis. (Legend: bias: biodiversity assessment; serv: ecosystems services; geod: geographic distribution; habc: habitat conservation; moni: monitoring; popb: population biology; popv: population viability; thre: threatened biodiversity; educ: education; exmn: ex situ species management; hbmn: habitat management; infr: infrastructure; inst: instruments for conservation; spmn: species management; stuse: sustainable use of biodiversity; tech: technologies).

and conservation. Successful conservation actions must use a clear communicative channel involving different cultures and scientific propositions in order to build a shared framework (Schulte et al. 2006). For Meffe (1998), this framework is only possible if scientific knowledge becomes accessible to the population and policy makers in a proper educational form designed for each of the cultural components of the society.
From this perspective, scientific research provides the basis for preservation, management and restoration of biodiversity to Conservation Biology, which offers theoretical and analytical tools for the identification of threatened or rare species or for presenting technical suggestions to ecosystem management. In addition, Tracy \& Brussard (1996) admit that conservationist actions without a scientific basis are frequently simplistic and may accelerate extinctions instead of promoting conservation.

It appears that a specialized scientist dealing with biological diversity feels somewhat uncomfortable becoming involved with the social consequences of the economic use of biodiversity commodities. The solution to this complexity comes out of mere personal interest. No one may ignore the underdeveloped stage of the interdisciplinary groups of research, which may be a cause and a consequence of the distance between theory and practice. These interactions, as shown here, are difficult for researchers in Conservation Biology in spite of the importance of social movements to promote conservation biology goals.

As the specialists became more specialized, growing knowledge of political sciences, social skills and communication aspects for interventionist approaches (Jacobson 1990) may exist only in multi-disciplinary proposals. However, this approach may have more impact if the conservation professional is also more aware of the human dimensions (beliefs, values, attitudes, behaviors and other characteristics of stakeholders) that affect conservation of natural resources (Jacobson \& McDuff 1998). A key-factor to change is the education of the conservation professional. It should explicitly include the social context of conservation and training in politics, economics and communication (Jacobson \& McDuff 1998; Clark 2001), and it should emphasize dealing with multi-disciplinary research questions.

We recognize the difficulties in balancing the need for a clearly stated theoretical basis for conservation and well-proposed practical actions. We also adhere to the view that effective conservation may occur in the middle ground between those approaches. Nevertheless, there are some Brazilian examples of conservation models that include research and action in an effective way. Good examples of conservation actions that are well linked to ecological research are the marine turtles project (Almeida \& Mendes 2007), the study of endangered mammals at the Pontal do Paranapanema followed by the establishment of a net of conservation units (Valladares-Padua et al. 2002) and studies related to the use of natural resources by traditional populations, mainly in the Amazon region (e.g., Silvano et al. 2008). For instance, an effective conservation model may begin as a proposal to assess the biodiversity in a region. The next step would be to initiate studies about species biology, population viability, geographic distribution and monitoring, which represent basic knowledge about population and communities to outline conservation goals. Species management and sustainable use of biological resources are clearly dependent on such scientific information. Scientific studies that aim 
to evaluate ecosystem services or bio-prospect resources could subsidize conservationists' practices that, for example, look for increased income for local people.

Otherwise, our results point out that habitat conservation and management show the only successful association between theoretical and practical issues. This association may have resulted from the perception that the habitat is the simplest theoretical concept that could be easily translated to action. The lack of association with population biology may also have resulted from the shortage of basic biological information on threatened species, which is considered one of the most important problems for conservation actions in the Neotropical realm.

However, research agendas in conservation can encourage projects with better organization and more properly designed interactions of biological research and intervention actions, which may influence scientists to produce more clear relations between the theoretical and methodological aspects of their investigations.

\section{Acknowledgements}

Thanks to National Council of Technological and Scientific Development $(\mathrm{CNPq})$ - Brazil for a research grant to F. P. L. and the productivity grant to P. D. M. Jr.

\section{References}

Almeida AD \& Mendes SL, 2007. An analysis of the role of local fishermen in the conservation of the loggerhead turtle (Caretta caretta) in Pontal do Ipiranga, Linhares, ES, Brazil. Biological Conservation, 134:106-112.

Beissinger SR, 1990. On the limits and directions of conservation biology. BioScience, 40:456-457.

Berk RA \& Rossi PH, 1999. Thinking about program evaluation. London: SAGE Publications.

Caughley G, 1994. Directions in conservation biology. Journal of Animal Ecology, 63:215-244.

Clark T, 2001. Developing policy-oriented curricula for conservation biology: professional and leadership education in the public interest. Conservation Biology, 15:31-39.

Costanza R et al., 1997. The value of the world's ecosystem services and natural capital. Nature, 387:253-260.

Everitt BS \& Dunn G, 1991. Applied multivariate data analysis. London: Edward Arnold.

Ford ED, 2000. Scientific method for ecological research. Cambridge: Cambridge University Press.
Fundo Nacional do Meio Ambiente, 2002. Catálogo de Experiências 1990-2001. Brasília: Fundo Nacional do Meio Ambiente.

Jacobson SK, 1990. Graduate education in conservation biology. Conservation Biology, 4:431-440.

Jacobson SK \& McDuff MD, 1998. Training idiot savants: the lack of human dimensions in conservation biology. Conservation Biology, 12:263-267.

Meffe GK, 1998. Conservation scientists and the policy process. Conservation Biology, 12:741-742.

Pickett STA, Kolasa J \& Jones CG, 1994. Ecological understanding. San Diego: Academic Press.

Salafsky $\mathrm{N}$ et al., 2002. Improving the practice of conservation: a conceptual framework and research agenda for conservation science. Conservation Biology, 16:1469-1479.

Scheirer MA, 1994. Designing and using process evaluation. In Wholey JS, Hatry HP \& Newcomer KE (eds.). Handbook of practical program evaluation. San Francisco: Jossey-Bass Publishers. p. 40-68.

Schulte LA et al., 2006. Evaluating the conceptual tools for forest biodiversity conservation and their implementation in the US. Forest Ecology and Management, 232:1-11.

Silvano RAM et al., 2008. Contributions of of ethnobiology to the conservation of tropical rivers and streams. Aquatic Conservation: Marine and Freshwater Ecosystems, 18:241-260.

Soule ME, 1985. What is conservation biology? BiosScience, 35:727-734.

Stem C et al., 2005. Monitoring and evaluation in conservation: a review of trends and approaches. Conservation Biology, 19:295-309.

Sutherland WJ, 2001. The conservation handbook: research, management and policy. London: Blackwell Science.

Tracy CR \& Brussard PF, 1996. The importance of science in conservation biology. Conservation Biology, 10:918-919.

Trombulak SC et al., 2004. Principles of conservation biology: recommended guidelines for conservation literacy from the education committee of the society for conservation biology. Conservation Biology, 18:1180-1190.

Valladares-Padua C, Padua SM \& Cullen J, 2002. Within and surrounding the Morro do Diabo State Park: biological value, conflicts, mitigation and sustainable development alternatives. Environmental Science \& Policy, 5:69-7

Wilson EO, 1985. The biological diversity crisis. BiosScience, 35:700-706.

With KA, 1997. The theory of conservation biology. Conservation Biology, 11:1436-1440. 